\title{
Training school librarians for the information age: the case of South African teachers on the margins
}

\author{
Zinn, Sandy
}

\section{Introduction and Motivation for the study}

All indications are of a pressing need for school librarians (also referred to as teacherlibrarians) as information workers to comfortably navigate analogue and online information in a seamless way. Students today are born into a digital world of always switched on. South Africa is contending with Generation $\mathrm{Y}$ and $\mathrm{Z}$ in universities and schools respectively. There is a need for school librarians to both experience this world and to be critical of it.

In the Western Cape where the study took place, there is a sense of urgency to transport citizens into the world of the Internet. Most people in South Africa access the Internet on their mobile phones (Internet World Statistics 2016). But Internet access has been prohibitively expensive. South Africa's Internet penetration stands at $49 \%$ of the population. A recent study on Internet usage in the Western Cape Province revealed that residential households were spending more than $20 \%$ of their monthly income on connectivity. South Africa's Internet costs rank among the highest in the world. According to the International Telecommunication Union, anything more than 5\% is not affordable. On 16 March 2016, the Western Cape Government launched the first 50 of 384 planned public access Wi-Fi hotspots. The majority $(76 \%)$ of these hotspots are located on school walls facing public roads. Users can access $250 \mathrm{MB}$ for free per month and purchase additional data at competitive prices. The intention is to improve digital literacy, decrease the digital divide, support access for educational purposes, and more generally, improve access to information for decision-making (Western Cape Government, 2016).

The literature encourages the school library fraternity to embrace the digital world of the $21^{\text {st }}$ century. The new IFLA School Library Guidelines $(2015, \mathrm{p} 27)$ proposes that the curriculum for school librarians should include, "in addition to the core competencies of librarianship, an understanding of ... digital technology and social media". The South African LIS Tansformation Charter (2014) speaks of school libraries as "dynamic multimedia learning centres ... [and] their crucial role in education for the twenty-first century". The South African National Guidelines for School Library and Information Services (2012, p36) incorporate digital literacy, defined as "the ability to appreciate the potential of ICT to support innovation in industrial, business, learning and creative processes". The National Guidelines recognise that students "need to have the confidence, skills and discrimination to adopt ICT in appropriate ways".

\section{Research Questions}

Within the context of a worldwide drive for everyone to see the usefulness of ICTs for almost every aspect of one's existence, how do teachers training to become school librarians navigate circumstances fraught with both personal and extrinsic obstacles?

The following research questions guided this study:

- At what level is the teachers' Internet literacy?

- What are teachers' perceptions of their role as information providers in the $21^{\text {st }}$ century?

- Is the ICT face of information literacy more predominant because of the lack of school libraries in South Africa? 


\section{Literature Review}

The review depicts the context of education in South Africa and provides insight into national ICT initiatives as well as local Western Cape initiatives where the study took place. The review also addresses aspects of teacher training and school librarian training.

\section{SA education context}

The declaration of South Africa as one nation in 1994 did not miraculously give rise to an equal society with equal access to education. Twenty-two years later, we still have a very divided South Africa, socially, economically, and educationally. The greatest percentages of people who are poor and marginalized remain black (using black in the generic sense of those not classified white under the apartheid regime). Often the education literature refers to a "dualistic schooling system" (Spaull 2012, 426), a "bifurcated education system" (Bloch 2009) in which South African schools continue to be divided by privilege based essentially on past apartheid schooling structures. While schooling is theoretically "free" for the first nine years, access to quality schooling must be paid for.

South Africa has the worst education system amongst middle-income countries such as Turkey, Brazil, China, the Russian Federation and Namibia. These comparisons are based on the international testing that countries participate in such as TIMSS (2011), PIRLS (2011) and SAQMEC III (2011). Embarrassingly, South Africa performs worse than some low-income African countries. South Africa also has its homegrown version of the international tests for literacy and numeracy called the Annual National Assessments (ANAs) that have been taking place since 2011 for grades 1, 3, 6, and 9 but which teachers revolted against in 2015. In 2014 (Report of the ANA of 2014: P8-10) the ANA results for grade 9 mathematics averaged 11\%, home language was $48 \%$, and first additional language was $34 \%$. Only $18 \%$ of learners averaged above $50 \%$ for additional language, which is usually English. "Most South African pupils cannot read, write and compute at grade-appropriate levels, with large proportions being functionally illiterate and innumerate" (Spaull 2013, 3). As it stands, the South African education system is grossly inefficient, severely underperforming and egregiously unfair (Spaull 2013, 3). These two education systems can be seen when splitting pupils by wealth, socio-economic status, geographic location and language (Spaull 2013, p6). The gap between the $75-80 \%$ of failing schools and $15-20 \%$ of successful schools grows as students move from grades $1-12$. By the time students reach grade 12 , remediation is virtually impossible.

\section{Training of teachers}

Teacher training has been under the spotlight recently both in terms of initial teacher education and in-service teacher training.

Two studies on primary school education (Grades K-7) have recently been released. The first study by Taylor (2015) focuses on initial teacher education for the primary school level. This study, undertaken at five universities, identified instruction in literacy as deficient. This finding disregards numerous studies such as PIRLS that highlighted that $75 \%$ of Grades $4-6$ do not read with understanding. Nor are the universities preparing teachers adequately to teach English as a first additional language, which is the medium of instruction from Grade 4 onwards.

The second study by Van der Berg, et al (2016) identified four challenges that need to be addressed if there are to be improved educational outcomes for the poor (the marginalized). 
Amongst these challenges were "weak teacher content knowledge and pedagogical skill". This study corroborates Taylor's findings about teaching and learning in the primary school. " $60 \%$ of South African children do not learn to read for meaning in any language by the end of Grade 3" (Van der Berg, et al, 2016, p5) and " $44 \%$ of Grade 4 students had not written any paragraphs during the entire school year" (Van der Berg, et al, 2016, p9). Learning to read for pleasure and meaning in the primary school is a core skill upon which all types of learning builds. A reading deficit has a knock-on effect because learning other subjects becomes difficult if not impossible. Surprisingly, the reading crisis is not only based on African language students' lack of English acquisition, but it also appears as if mother tongue English and Afrikaans students (only 57\% of Grade 5 students could read for meaning) have not mastered reading for meaning in the primary school.

\section{Education and Training of school librarians}

The education and training of school librarians in South Africa follows two different paths primarily because the government does not fund the post of teacher-librarians in schools. The informal path or non-formal qualification route is met by Non-Profit Organisations such as The Bookery, and short learning programmes such as those newly offered by the University of the Free State (School Library Management and Administration) and the University of South Africa (Children and Youth Librarianship). The latter two short learning programmes are being offered purely as online distance learning courses. As they have only started this year, their success has not yet been established/measured, but should make for an interesting study into learning with technology or ICTs.

There are only three universities (out of 26 universities in South Africa) offering formal qualifications for school librarians: the University of the Western Cape (UWC), the University of KwaZulu-Natal (UKZN), and the University of Zululand (UNIZUL). UWC's Advanced Certificate in Education (ACE): school librarianship offered a specific course addressing school libraries in the digital era called ICT applications in school libraries. In this course teachers-in-training to become school librarians were taught about Library 2.0, social media usage in the school library, e-books, plagiarism in the digital age, internet filtering and ethical uses of information, and how to construct a website. This UWC School Library programme has been consciously addressing the Guidelines and LIS Transformation Charter in preparing school librarians for the $21^{\text {st }}$ century digital world. Other courses in which ICTs were integrated were Information Sources as well as Information Literacy Education. UKZN's ACE: School library development and management programme offered Using ICTS to access and retrieve information and manage school libraries (Hoskins, 2006). UNIZUL's Diploma in Specialised Education: School Librarianship offered more basic training in computer literacy such as Microsoft Word and Excel as well as an introduction to email, the Internet, the learning management system, and navigating e-resources (Evans, 2014). Evans (2014), in his University of Zululand study, lamented the poor English skills of the teachers that echo the later study results of Taylor (2015) and Van der Berg et al (2016). He makes a poignant connection between the teachers' poor understanding of English and their inability to access the Internet that offers information predominantly in English.

\section{ICTs in Education [incomplete]}

- 2025 vision for education in South Africa

○ High level literacy

- Prepare students for independent research at tertiary level 
○ Demands learners undertake research assignments taking them beyond the textbook

- Preparing learners for $21^{\text {st }}$ century world.

- Access to Internet.

- Western Cape Education Department (WCED) vision for e-education 2012.

- 2004 white paper on e-education South Africa

- http://e-classroom.co.za/ - this website provides access to worksheets for free for a few subjects such as maths, science, social science, all one has to do is register.

- http://wcedeportal.co.za/ - e-resources: online textbooks (for purchase); teachers' resources including Nalibali videos; and much more.

- http://www.cozacares.co.za/ -

- http://www.nolwazi.co.za/ - OERs and subsidiary of Cozacares

- http://testing.wcape.school.za/elearn/ - WCED using Moodle as LMS - uptake? unlike SAIDE, content is tightly behind firewalls

- http://www.saide.org.za/ - uses OERs

- http://trainingteachers.org.za/ - PETS stands for the Project for Educator Training in Schools. It's a project that uses technology to enable teachers to deliver better lessons Mathematics. It uses a method of self-managed learning that has been highly successful in continuing education for health professionals, adapted for teachers and educational assistants.

- http://rethinkeducation.co.za/ - app developers (e.g. Bambisa) and content mainly maths and science

- Tensions between print vs electronic

- http://www.iea.nl/ International Association for the Evaluation of Educational Achievement's new International Computer and Information Literacy Study (ICILS 2014) revealed that 'only $2 \%$ of students use their critical thinking and teachers lack confidence in teaching essential ICT skills'. ICILS is a first-of-its-kind study that assesses the digital competences of students worldwide.

\section{Theoretical and conceptual frameworks [Incomplete]}

\section{Info poverty approaches:}

- Chatman (2000): "The social and economic conditions of marginalization impacted the information behavior of different population" "She explained that people live in an impoverished information world when they are unwilling or unable to approach potentially helpful information sources, and when they engage in secretive and selfprotective behaviors to hide information needs from those who might be able to help them" "As her work progressed, Chatman found that information poverty was not necessarily a direct result of economic poverty but rather it was closely linked to a set of socially determined attitudes and norms". My study is no neat fit into her information poverty approach. Seems like a deficiency model.

- Social justice-based \& human rights based approach: The educational discourse particularly in government circles tend to view education rather narrowly using/in a human capital approach. Often the discourse is about education for employability rather than education for critical engagement with the world. In the former approach there is a sense that, if the deprived student is provided/ dropped into a more fortunate educational setting, or given the means to be educated, then these students should automatically be successful. But this success is measured mostly in employability, and 
employability in a society still dominated by a white person's world. [see Soudien 2013, Bloch 2009?, Tikly 2009? Also Sen's Development as Freedom]

- ICT4D and Digital Divide

Change agency/ Personal agency:

- Oberg (2009): librarians as change agents

- Michael Fullan

- Bandura: social cognitive theory?

- Hart's article on school librarians and leadership (South Africa)

- Ash and Persall (2000). "Formative Leadership Theory is based on the belief that there are numerous leadership possibilities and many leaders within the school. Leadership is not role-specific, reserved only for administrators; rather, the job of the school leader is to facilitate learning opportunities for the faculty and staff in order that they might develop into productive leaders. This theory of leadership supports the view of the teacher-librarian as leader".

- Johnston, M. (2012). Uses Distributed-Leadership Theory investigating enablers and barriers to school librarians' leadership role in technology.

\section{Methodology}

This study is a subset of a qualitative study investigating teachers' competency in information literacy education. The study used several data collection tools such as interviews, mind maps, observation, journals and project artifacts. This report focuses on observation and interviews with the teachers and head curriculum advisors in the education districts. What follows are selected statistical educational data about the Western Cape Province and a description of the teachers in the study.

\section{Statistics for the Western Cape Province}

Annually, the Department of Basic Education provides school statistics. The latest is for 2015 which states that the Western Cape has 1460 public schools (EMIS School Realities 2015, p1) of which $87 \%$ have Internet access (NEIMS Standard Report, Table 11, p4,). There are computer centres in $41 \%$ of schools, mostly located in high schools. Schools with a stocked library amount to $29.93 \%$ (therefore $70,07 \%$ have no library) (NEIMS p4). There are, however, no statistics for school librarians as formal positions for school librarians do not exist in schools. The languages spoken in the Western Cape are Afrikaans (49.7\%), isiXhosa (24.7\%), and English (20.3\%) according to Statistics South Africa (Statssa 2011). However, the medium of instruction in schools is supposed to be English from Grades 4-12.

\section{School Libraries in the Western Cape Province}

In 2005 the Cabinet approved funds intended for equalising education and providing basic resources to the poorest schools. It was called the Quality Improvement, Development, Support and Upliftment Programme or QIDS-UP. The Western Cape Government's research advocated for a library and trained librarian. The Western Cape Government used the QIDSUP fund of more than R100-million to provide start-up libraries in all quintiles 1-3 schools. The quintile system is an economic division of schools into categories from 1 to 5,1 being the poorest schools and 5 being the wealthiest schools. The fund also covered shelving, furniture, computers, library administration software and teacher training in library administration. The project's intention was to improve access to attractive reading material for better literacy and numeracy at poorer schools. Since the rollout of the project in 2007, 672 schools in quintiles 1-3 were provided with processed library material (covered and classified). In essence, 46\% of schools were potentially stocked, yet the current central statistics mention about $30 \%$. How does one account for the shortfall? A snap survey was conducted in 2013 by school library 
advisors in four education districts. They reported that 87 school libraries were in full use, 38 were in partial use, 54 were definitely not used and 76 were unaccounted for. In fact, many schools had not unpacked the boxes of library material received from the QIDS-UP project or organised them into a readily accessible collection.

\section{Participants in the study}

The teachers who volunteered to be part of the study were training to become school librarians at the University of the Western Cape. The majority were female (27 out of 29). They came from both urban and rural schools of which $20(70 \%)$ were classified as quintiles 1 and 2 schools, the economically poorest schools. The average age of the teachers was 45 years. The majority (22) were teaching in primary schools. The dominant home language was Afrikaans (17), followed equally by English (6) and isiXhosa (6). Four schools had partially functioning school libraries. Public libraries less than $3 \mathrm{~km}$ away were accessible to about $43 \%$ of the schools. Twenty-five schools had computer centres with between 20 and 25 work stations, but Internet access on these computers varied between 3 and 25 computers. More teachers (19) had computers at home than had Internet access (8). Teachers responded to questions about the importance of using the new literacies of the Internet for themselves and for teaching. The were asked how they incorporate the Internet into their lessons and how important is was for students to access the Internet. They were also asked if they influenced their colleagues to use the Internet.

Six Heads of Curriculum in the education districts were interviewed at their district offices. Three were based in rural areas and three in urban areas. These Curriculum Heads have teams of advisors working under them who advise teachers on subject curricular matters. Cuuriculum Advisors are expected to implement curriculum policy, provide subject guidance to teachers, offer expert views on assessment, facilitate workshops with teachers, and monitor teachers' progress and development in teaching in their subject/s. The Curriculum Heads offer a bird's-eye view (vantage point) of both teachers and the demands of curriculum execution. In the interviews, they were asked their understanding of information literacy, their views on the computer centres at schools and the state of Internet access for teachers, training for teachers in use of the computers and Internet, and teachers' ICT skills and knowledge.

\section{Findings \& Discussion [Incomplete]}

The teachers in the study had participated in several courses in the ACE: School Librarianship programme that demanded the use of computers and the Internet: namely, Information Sources, Information Literacy Education, and ICT Applications in School Libraries. The observation of teachers in the computer laboratory and the reactions to interviews are

combined to create a composite profile of the teachers' in this study. The findings will be discussed under the research questions with teachers referred to by number e.g. teacher \#6 and curriculum advisors by pseudonym to maintain anonymity.

\section{At what level is the teachers' Internet literacy?}

The first observation of teachers using technology in this study occurred in a computer laboratory. As the lecturer of the information literacy education and ICT applications in school libraries courses who had worked as a curriculum advisor for the WCED, two assumptions were made: firstly, as most teachers in the Western Cape have had basic computer literacy training, the assumption was that teachers could open a Word document, save it, copy and paste into Word, and use tabs to work with different documents simultaneously. The WCED ICT project which started in 2001, rolled out computers to 
schools first for administrative purposes, followed by the establishment of computer laboratories in all schools for curriculum delivery, especially for literacy and numeracy in the primary schools and mathematics and science in the high schools. Most teachers were given basic computer and Internet training as part of this project. The second assumption was that the teachers had already completed the information sources course for which they had to use computers to access databases and the Internet. The instruction to teachers was to locate five useful websites for each of the eight school subjects. Based on the assumptions, the exercise should have been straightforward, but it turned out to be exacting. Teachers could not toggle between Word tabs and Web tabs, teachers copied and pasted into the ether ending up with blank documents, and search engines remained a mystery to them. Clarke's master's thesis (2010: 75) focusing on the WCED ICT project concluded that the promised development of teachers by the project did not receive the level of training required for curriculum integration. Basic computer literacy does not suffice in training teachers to use ICTs for teaching and learning.

During observation it became apparent that teachers \#1 and \#2 are confident Internet users. They are tasked with assisting the others. Teacher \#1 remarked that there is limited information in Afrikaans on the Web, Afrikaans being the home language of most of the teachers and students in the Western Cape. Czerniewicz and Brown (2005) made a similar observation in their South African study of access to ICTs for teaching and learning, confirming participant \#1's remark. English remains the dominant language of African producers of Internet content despite English being the home language of a minority of the population. For this reason teachers were introduced to the Weblinks Research database which offered links to selected websites per subject per grade, and included Afrikaans websites.

When teachers started the school librarianship programme, their use of the Internet was minimal. They had to be introduced to email and using search engines to locate information online. Even when their respective schools had banks of computers and Internet access, their lack of confidence in using technology prevented them from recognizing the value of Webbased information. The teachers were most comfortable using and promoting books and print, thus moving teachers into the world of the Internet took them out of their comfort zone. There were teachers (\#5, \#13, and \#24) who were total technophobes at the beginning. A Grade 7 teacher (\#13) says she always felt limited by the information she was finding in books in the library but she dreaded the computer. She called the computer "the monster". A teacher already on the doorstep of retirement, she became an Internet convert once she cleared the obstacles in her mind.

By the end of the programme the teachers were using the Internet in a variety of ways:

\begin{tabular}{|l|l|l|}
\hline What are teachers doing online? & $\mathbf{n = 2 9}$ & $\begin{array}{l}\text { Who explicitly mentions these } \\
\text { tools and services }\end{array}$ \\
\hline $\begin{array}{l}\text { Finding personal information such as health, } \\
\text { sport, devotions }\end{array}$ & 28 & Only \#12 was not using the Internet \\
\hline Emailing & 18 & $\begin{array}{l}\# 1 ; \# 4 ; \# 10 ; \# 11 ; \# 13 ; \# 16 ; \# 17 ; \\
\# 18 ; \# 19 ; \# 21 ; \# 22 ; \# 23 ; \# 24 ; \# 25 ; \\
\# 26 ; \# 27 ; \# 28 ; \# 29\end{array}$ \\
\hline
\end{tabular}




\begin{tabular}{|l|l|l|}
\hline E-filing tax returns & 14 & $\begin{array}{l}\# 3 ; \# 4 ; \# 9 ; \# 11 ; \# 14 ; \# 17 ; \# 18 ; \# 19 ; \\
\# 22 ; \# 21 ; \# 23 ; \# 24 ; \# 25 ; \# 29\end{array}$ \\
\hline Facebook & 12 & $\begin{array}{l}\# 4 ; \# 11 ; \# 13 ; \# 14 ; \# 17 ; \# 18 ; \# 21 ; \\
\# 22 ; \# 25 ; \# 27 ; \# 28 ; \# 29\end{array}$ \\
\hline Blogging and Wikis & 5 & $\# 4 ; \# 13 ; \# 14 ; \# 19 ; \# 22$ \\
\hline Internet banking & 4 & $\# 3 ; \# 11 ; \# 21 ; \# 29$ \\
\hline $\begin{array}{l}\text { Checking the WCED website for: curriculum } \\
\text { news; Grade } 12 \text { forms; jobs bulletin; exam } \\
\text { papers and memos }\end{array}$ & 3 & $\# 16 ; \# 19 ; \# 22$ \\
\hline $\begin{array}{l}\text { Online purchases: theatre tickets, airline } \\
\text { tickets }\end{array}$ & 3 & $\# 11 ; \# 24 ; \# 27$ \\
\hline Reading the news & 2 & $\# 4 ; \# 17$ \\
\hline Check personal credit report & 1 & $\# 4$ \\
\hline Other social media: Twitter; YouTube & 1 & $\# 29$ \\
\hline Listservs & 1 & $\# 19$ \\
\hline Online storage of documents & 1 & $\# 27$ \\
\hline
\end{tabular}

What are teachers' perceptions of their role as information providers in the $21^{\text {st }}$ century?

Is the ICT face of information literacy more predominant because of the lack of school libraries in South Africa?

- 2004 White Paper on e-education contains ICT literacy spelled out as in information fluency.

- The LIS Transformation Charter (2014) talks about information literacy coupled with ICT literacy.

- Computer Assisted Technology (CAT) school subject's information management outcomes resemble information literacy exactly. Teacher \#28 formed an alliance with the CAT teacher because they were talking the "same language".

- Heads of Curriculum conflate information literacy and ICTs.

- The first base-line study of information literacy in South Africa was skewed towards ICTs (Laura Czerniewicz 1999). It featured ICTs as a part of information literacy. Future references to information literacy would arise most strongly within the ICT field rather than school education purely. Boekhorst and Britz (2004) are of the same mind when they argue in their comparison of the Dutch and South African education systems that information literacy has been captured most convincingly in the ICT curriculum. The ICT face of information literacy (Bruce 1997) is more in evidence as a result of minimal school libraries in South Africa.

\section{Conclusion \& Recommendations [To follow]}


- If information literacy is deemed synonymous with ICTs, those who have ICTs may be blinded into viewing the technology as a panacea for their pedagogical woes.

\section{References [Incomplete]}

Boekhorst, A.K. \& Britz, J.J. (2004). Information literacy at school level: a comparative study between The Netherlands and South Africa. South African journal of libraries and information science, 70(2): 63-71.

Combes, B. (2006). [DVD]. Techno savvy and all-knowing or techno-oriented? Information seeking behaviour and the Net generation. In Martins, A.B., Falcao, A.P, Conde, E., Andrade, I., Nunes, N.B., Vitorino, M.J. (eds). IASL reports 2006: the multiple faces of literacy: reading knowing, doing - IASL reports, 2006. Selected papers from the 35th Annual Conference of the International Association of School Librarianship and the 10th International Forum on Research in School Librarianship, Lisbon, Portugal, 3-7 July 2006. Erie, PA: International Association of School Librarianship.

Czerniewicz, L. (1999). Information literacy in schools in the Western Cape: a preliminary study: a report prepared for the INFOLIT Project of the Adamastor Trust. Rondebosch, Cape Town: Adamastor Trust.

Czerniewicz, L. \& Brown, C. (2005). Access to ICTs for teaching and learning - from single artifact to inter-related resources. International journal of education and development using ICT, 1(2). Retrieved November 22, 2007, from http://ijedict.dec.uwi.edu/viewarticle.php?id=38

Evans, N.D. (20140. Training teacher-librarians to establish and manage school libraries in KwaZulu-Natal: an empirical study. Mousaion, 32(2),106-123.

Fullan, M. (1993). Why teachers must become change agents. Educational leadership, 50(6): $1-13$.

Hoskins, R. (2006). Libraries and teacher-librarians in KwaZulu-Natal. Innovation: journal of appropriate librarianship and information work in Southern Africa, 33: 59-75.

International Federation of Library Associations and Institutions (IFLA). (2015). IFLA school library guidelines, 2nd revised ed. Edited by B. Schultz-Jones and D. Oberg, with contributions from the International Association of School Librarianship Executive Board. The Hague: International Federation of Library Associations and Institutions.

Henri, J. \& Oberg, D. (2005). The leadership role of the principal in the information literate school community. In Henri, J. \& Asselin, M. (eds). Leadership issues in the information literate school community. Westport, CT: Libraries Unlimited: 79-91.

Internet World Statistics. 2016. South Africa.

Johnston, M. (2012). School librarians as technology integration leaders: Enablers and Barriers to Leadership Enactment. School Library Research, 15. Retrieved May 25, 2014 from www.ala.org/aasl/slr 
The Library and Information Services (LIS) Transformation Charter. (2014). Pretoria: Department of Arts and Culture and National Council for Library and Information Services. Retrieved December 6, 2014, from http://www.nlsa.ac.za/Downloads_01/2014 Final_LIS_Transformation_Charter.pdf.

Van der Berg, S., Spaull, N., Wills, G., Gustafsson, M. \& Lotze, J. (2016). Identifying binding constraints in education: synthesis report for the programme to support pro-poor policy development. Retrieved May 4, 2016, from http://resep.sun.ac.za.

Bloch, G. (2009). The toxic mix: what's wrong with South Africa's schools and how to fix it. Cape Town: Tafelberg. 379.68

Oberg, D. (2009). Libraries in Schools: Essential contexts for studying organizational change and culture. Library Trends. 58(1),9-25.

Taylor, N. (2015). Initial teacher education research project. Phase II: from research to action. Retrieved May 4, 2016, from http://www.jet.org.za.

Spaull, N. (2012). Poverty and Privilege: Primary School Inequality in South Africa. Stellenbosch EconomicWorking Papers 13/12. Stellenbosch: University of Stellenbosch, Department of Economics.

South Africa. (2004). White paper on e-education: transforming learning and teaching through information and communication technologies. Pretoria: Department of Education. Retrieved January 23, 2016, from CHECK URL ONLINE

South Africa. 2011a. Curriculum and Assessment Policy Statement (CAPS): Computer Applications Technology (CAT). Pretoria: Department of Basic Education. Retrieved January 18, 2016, from http://www.education.gov.za.

South Africa. (2014a). NEIMS Standard Reports October 2014. Pretoria: Department of Basic Education. Retrieved November 4, 2014, from http:/www.education.gov.za/.

South Africa. (2014b). Report on the Annual National Assessment (ANA) of 2014. Pretoria: Department of Basic Education. Retrieved October 30, 2015, from http://www.education.gov.za.

South Africa. (2014c). School Realities 2014. Pretoria: Department of Basic Education. Retrieved August 12, 2015, from http://www.education.gov.za.

South Africa. (2012). National guidelines for school library and information services. Pretoria: Department of Basic Education.

Western Cape Government. (2016). Limited free Wi-Fi in the Western Cape. Retrieved March 10, 2016, from https://www.westerncape.gov.za/documents/public info/limited-freepublic-wi-fi-western-cape 